THURSDAY, JANUARY I, 1903.

THE UNIVERSITY IN THE MODERN STATE. A MONG the many documents prepared by Principal A Sir Oliver Lodge in relation to the development of the University of Birmingham, there are more than one of which the interest is by no means merely local. Of these, the pamphlet entitled "Survey of the Sciences," which forms an appendix to a paper on University Development, is of especial importance at the present time, for we are glad to know that the belief that the weakness of our universities must lead to national weakness in several directions is growing with a rapidly accelerating pace.

It may be long in this slow-moving country before the influence of Brain-power on history is recognised as fully as the influence of Sea-power has been, thanks to Captain Mahan, but undoubtedly it will be bad for our future if much more time is lost.

While Sir Oliver Lodge has been investigating the "needs" of Birmingham, similar inquiries have been made elsewhere, and we have received from the Clarendon Press a statement of the "needs" of Oxford. We are glad to see that the Times, in a sympathetic article, goes to the root of the matter in stating that "if the pocket of the millionaire is closed, the pocket of the nation must be opened." Our eleven universities are competing with I 34 State and privately endowed in the United States and twenty-two State endowed in Germany. English private endowment is much less than Io per cent. of the American endowment, and the German State gives to one university more than the British Government allows to all the universities and university colleges in England, Ireland, Scotland and Wales put together. These are the conditions which regulate the production of brainpower in the United States, Germany and Britain respectively, so far as Universities are concerned, conditions which Sir Oliver Lodge proposes to face as manfully as he may. His paper on the "Survey of the Sciences" runs as follows :-

In a recent pamphiet I considered the question of the relation of the University of Birmingham to its central and suburban sites, with a view of determining what recommendation should be made to the Council concerning the Departments which ought to migrate and the Departments which ought to remain. I was able to arrive at some judgment on the matter except in connection with the Faculty of Science, and there the problem became so complicated that it was necessary to make a survey of the sciences in order to get the material on which to form an opinion. This survey is now printed, not only as an appendix to the former paper, but because it is hoped that it may be useful for other purposes; especially I hope that it may be of interest to those who are able to help financially in the forth coming great educational development of the future, enabling them to realise the immensity of the area which we attempt to cover, and the largeness of the sum which could be properly invested in suitable buildings and equipment and in endowment of staff. Our position is such that if some man of power thought fit to exercise it by entrusting us with a sum of five millions for University development, it could be well and properly employed ; ${ }^{1}$ nor could such an investment fail to exercise an extraordinary influence on the progress of the country. Hitherto the ideas of this country in education and scientific research have been conceived on a wholly inadequate scale,

$$
1 \text { See "Concluding explanation." }
$$

No. I73I, vOL. 67] and without proper appreciation of the vast extent of territory over which a modern University is called upon to preside.

Let us, therefore, now run over the pure sciences, and trace the collateral branches and practical applications with which they are most allied; taking them in alphabetical order, and enumerating only those sciences with which we ourselves at present in some degree attempt to deal.

AnATOMY :-is clearly so closely allied to professional medicine as practically to have drifted out of general culture; though it is to be remembered that it is in touch with Fine Art on the one side-and a course of lectures on Artistic Anatomy is annually given by our Professor or our Lecturer at the School of Art-and on another side it is in touch with the sciences of ANTHROPOLOGY and Ethnology. At the present time the course of lectures and practical instruction in the subject of Anthropology, laid down in the Calendar as an optional subject for Degrees in Science, is under the charge of the Professor of Anatomy, who has made a study of this subject and of Ethnology, particularly from the side of Prehistoric Archæology, and on two occasions has given courses of lectures on these subjects, though at the present time the plant possessed for their teaching is not large. He possesses a collection of lantern slides of an ethnological character, also a private collection of stone and metal implements, and the Summers-Freer collection is now displayed in his department ; with it will shortly be exhibited-as a loan from the Geological Department to which it belongs-the Seton-Carr collection of early Egyptian stone implements; and there is, besides, a small collection of Palæolithic and Neolithic implements in the Geological Museum. A case of similar implements is in the City Museum, and there are a number of ethnological objects, some of considerable interest, in the Aston Hall Museum, which might, perhaps, become available some day for the purposes of the University.

On the practical side of colonial development modern Ethnology is a subject not altogether to be lost sight of.

ARCHAOLOGY :-A study of the past from relics and monuments and excavated sites: skilled interpretation of which enables us to reconstruct the life of ancient times. Our present Lercturer in Greek has made a special study of Greek Archæology.

BOTANY :-Studied with us partly for its own sake as a department of Natural History, allied to Horticulture and Gardening generally, and also from the point of view of Vegetable Physiology. This science is the foundation of much of Agriculture, of Forestry, of Materia Medica, of Timber and Plant diseases, the Fermentation industries, and of many human diseases. It is allied on its morphological side with Palæontology. On its Physiological side it is largely dependent on Physics and Chemistry.

At the present time it is not now taught as a separate subject in the medical curriculum at Birmingham, but admittedly only because the course is so crowded that something had to give way.

Chemistry :- This gigantic science branches out in every direction. Almost every manufacture is more or less directly concerned with it, and as a pure science it is a most important branch of Natural Philosophy in alliance with Physics.

In many places there is a Professor of its Inorganic and another of its Organic division: in Germany it is still further greatly subdivided, even from the point of view of the pure science. Flourishing departments of the new and growing science of Physical Chemistry exist at Leipzig and at other German and American Universities, in furtherance of pioneer work begun at Amsterdam and Stockholm.

As to the applications of Cliemistry, they are almost too numerous to mention, and every one of them demands the full time and special knowledge of an expert. At present we have only attempted Brewing and Metallurgy.

A training in elementary chemistry, both inorganic and organic, is universally recognised as an essential ingredient in the training of a medical student.

And recently Chemistry has allied itself, on the fermentation side, with a branch of Biology, through the discoveries of the great chemist Pasteur-a subject in which our present Professor and his wife are eminent.

ECONOMIC SCIENCE :-is a branch of Sociology or the theory of Politics, of which we have recognised the commanding importance, on one of its many sides, by arranging that there shall be hereafter constituted a Faculty of Commerce. In the hands of our present Professor there is no fear lest either the term. 
Economics or the term Commerce shall be interpreted too narrowly: the two will be welded to some extent into one, and gradually it is to be hoped that the treatment of these sub jects of national moment can be established on a sound and broad educational basis.

EndCATION or Pædagogy.-The science of Fducation is coming to the front of practical politics in a most impressive manner just now. All that we attempt in this direction at present is the Training of a limited number of Primary Teachers, both men and women : a department which constitutes a successful and promising beginning of a mosi important work. Bat some part of the barrier between primary and secondary education is shortly to be broken down, and the Government is wisely going to insist on a training for Secondary Teachers also. It is important to remember that, for this work, teaching must be provided in all departments of ordinary know. ledge, and by no means in the Arts subjects alone; though those no doubt constitute the backbone of the course. Also that methods of teaching the substance of Science (including Mathematics) and Modern Languages, in schools, are less developed and systematised than are the disciplinary methods for drilling in Ancient Languages, Euclid and Algebra. A Professorship is necessary if we are to enter into effective relations with and duly to influence secondary schools.

ENGINEFRING. -...This science is, even more than chemistry, overweighted with its own applications; so that there is a tendency to regard it solely as an applied science. But it has a large and most important pure-science aspect, too; and on this side may be considered to consist of Applied Mechanics and Physics; meaning by that, such subjects as Thermodynamics, Elasticity, Strength of Materials, Theory of Mechanism, and much else; not to mention the enormous subject of Electrotechnics-the foundation of Electrical and Telegraphic Engineering; in fact, the ground to be covered is so large that but few Physicists are competent to treat the whole science adequately from an engineering point of view, and so a good deal falls to the province of the Professor of Engineering. At the same time a thorough knowledge of the groundwork of the pure Science of Physics and Mechanics is essential to the training of every engineer who aspires to rise to the higher ranks of his profession.

We have only to run over the aspects of Civil Engineering in its limited customary sense--Bridges and Tunnels, lineservoirs, Canals and Railways ; and then to remember Marine Engineering and Military Engineering-to recognise that the whole sub. ject is obviously gigantic. It alone could cover the whole site and employ a dozen professors.

Geology. - The great science of the earth's crust claims to deal with the constitution and history of the earth as a whole. It is in touch on the one hand with Astronomy-a science which at present we do not here attempt-with GEOGRAPHY, a science which has many aspects, both on the side of nature and on the side of the distribution of man, which are dealt with to a considerable extent by our present Professor of Geology-with Mineralogy, which he also treats-with PAI..9ontology, the Botany and Zoology of the ancient world, in parts of which he is a world-known authority--with Physics and with Chemistry, more especially perhaps with Physics, for many of the probiems are the physics of the earth's crust. All this on the pure science side.

On the side of Applied Science it is in obvinusly close con nection with Mining, with Civil Engincering, with Water Supply and with Agriculture.

HISTORY :- the science of humanity in the past, is closely allied with Sociology and Economics; it is often treated in a more literary manner than most sciences, and hence is sometimes taken for a time by a Professor of Literature; but never satisfactorily so. The whole range of ancient and modern history, of events and institutions and of constitutions, is large enough to demand the attention of several specialists, if the ground is to be adequately covered.

On its practical side it has close relation with Law and with Commerce.

MATHEMATICS:-the science of number and form, in its elementary stage, is an essential ingredient in all education, and hence is partly associated with the Faculty of Arts. In its higher stages it is essential to the Engineer, and is becoming necessary to the Chemist ; and for these purposes a more immediatty practical course, proceeding more quickly over the rudimentary portions, is desired. In still higher stages it is essential to the Physicist, the Astronomer, and the Natural Philosopher generally. And in its highest stages it constitutes a pure science of unexampled beauty and perfection.

The so-called Applied Mathematics, or Theoretical Mechanics, is closely allied with, and, indeed, trenches upon the mathematical side of Physics; and there is ample room for two or more professors of the different branches of Mathematics. Some day this statement will become practical politics.

MEDICINE :-is the only science which at present is adequately treated in England. A five years' course is devoted to its acquisition; and it is subdivided into a proper number of constituent parts, each dealt with by a special Lecturer.

Besides the three great sciences Anatomy, Physiology, Path. ology, with which last at present the developing new science of Bacteriology is associated, there are the great practical Arts of Medicine and Surgery, together with the several branches called respectively Hygiene, Therapeutics, Materia Medica, Midwifery, Gynæcology, Forensic Medicine, Toxicology, Mental Diseases (the Pathological side of Psychology), Ophthalmology, each with a special Professor. Besides these we might have a Lecturer on Diseases of Children, another on the Ear and Throat ; and we have seven Lecturers in Dentistry, a branch in which we give special degrees. There is also Pharmacy, including the training of Pharmaceutical Druggists, a brauch of work we have not yet undertaken, but for which there is some demand.

Medicine therefore is a model according to which all the great sciences should be subdivided and conquered; and to some extent it is coming to be so in Germany. This country is ignorant of Science: and the administrative and commercial classes are not yet awake to its value.

PATHOLOGY. - This vitally important science used to consis wholly, and still consists largely, of post mortem operations and the study of fresh morbid specimens, with the object of throwing light upon the processes of disease; so that an essential appendage to the subject is its museum of morbid preparations which indeed subserves also many practical branches of Medicine and Surgery.

A good Pathological Museum is one of the most valuable assets of a Medical School, and has been found to be a powerful factor in attracting students, as well as in maintaining the incerest of medical practitioners, to whom it may be a considerable aid in difficult cases.

Nowadays the science has been illuminated and almost revolutionised by the discoveries of BACTERIOLOGY; and it bids fair to achieve for humanity the greatest service which on the terrestrial plane can be accomplished, viz., the earlier and surer recognition, the intelligent treatment, and ultimate removal, of many forms of disease.

The science is allied to Physiology, to Chemistry, to Zoology, and to Botany, and it is the root principle of Medicine and Surgery.

Its researches seem likely to open up the tropics to white habitation, thereby greatly enlarging the effective extent of the earth's surface; and, if it progresses as it has recently been doing, it is to be expected that the average duration of human life everywhere may be largely and efficiently prolonged.

Physiology.-This splendid science deals largely with the functions of the human body in health-indeed with organic or vital functions generally, save that those of the lower animals and of plants are generally relegated to the special sciences of Zoology and Botany. It is the Physics and Engineering and Chemistry of live machines. It is closely connected with Anatomy, which concerns itself with the discovery and enumeration of the structures themselves; and on the practical side it manifestly is closely related to Medicine. For a due understanding of the functions of the heart, the liver, the muscles, the lungs, the viscera, the nerves, the brain, the kidney, the stomach, the glands, the eye, the ear, and the other organs of the body, is essential to their proper treatment, whether by hygienic precautions or by remedial drugs; just as an exact anatomical knowledge of their position is the foundation of surgery.

The microscopic branch of Anatomy, called Histology, the science of the minute structure of the tissues, is generally at present dealt with by the Physiologist, doubtless because these parts are intimately concerned with the business of secretion and with vital functions generally.

It has recently been customary to equip the Physiologist with a quantity of elaborate Phy sical instruments, chiefly for a special

No. 1731 , VOL. 67$]$ 
study of the phenomena of nerves - in which of late years many discoveries have been made. The electrical concomitan's of nervous action have been found very helpful in elucidating the processes and determining their true relations, even if they do not turn out to be themselves an essential part of the process ; and accordingly the science demands extensive and expensive equipment.

From the side of the brain and nervous system it is related to the analysis of mental functions in Psychology.

Physics. - Of the science of Physics I dare hardly trust myself to speak : suffice it to say that it is the chief part of Natural Philosophy, the science which covers everything except the treatment of life and mind, and it underlies every other science. It seeks to explain the phenomena of Chemistry and of Pbysiology, so far as can be done without trenching on the domain of Biology. It is closely allied to AsTronomy, it measures sizes and distances, and the chemical constituents of the heavenly bodies. It is concerned with all exact measurements, with weighings and gaugings and surveyings, all geodetic operations, and a great part of Navigation. It includes Meteorology, which is the physics of the atmosphere; it deals with Heat and Light, and Sound, including the theory of Music, with Magnetism and Electricity, with waves and vortices, with the flow of fluids, with the elasticity of solids, with the theory of gases; and it is the foundation of Engineering.

On its practical side it has blossomed in every direction: witness the pump, the barometer, the telescope, the microscope, the photographic camera, the steam engine, the telegraph, the electric motor, the electric light, the X-rays; less obviously in a multitude of other directions.

On its theoretical side it is the most advanced and extensive of the whole of the family of sciences; and a much larger staff is necessary if we are to occupy its territory in even a moderately respectable manner.

In the department of exact measurement and mathematical electrical theory our present Professor of Physics has made for himself a world-wide reputation; and the limits of discovery in a science like this are controlled more by the lack of time and of material equipment than by almost anything else.

PHILOLOGY :- the scientific treatment of language : a com prehensive subject which ranges from a competent understanding of the derivation of words to an interpretation of Hieroglyphics and of Cuneiform inscriptions, to Palreography-or the study of Ancient Manuscripts. It is thus allied on one side to History, Sociology and Folklore, on another side to Ethnology and Archæology. It welds languages into families, and traces their relationships, and on its practical side is a necessary element in the thorough study of any modern language. It is a subject in various departments of which our Professor of Classics and Lecturer in Latin are experts.

PSYCHOLOGY :- may be regarded as the highest of all the biological sciences, being the theory of mind and of mental operations in general; in another aspect it constitutes the fundamental substratum of knowledge, being the study of the processes by which we recognise the external world, and all the facts dealt with by other sciences: it is a study which on its practical side is closely allied with Education, which so far as it is scientifically based must rest upon it. In recent times experimental methods have been applied to the simpler mental operations, thus giving to the subject increasing definiteness and precision; and a large extension of knowledge is being foreshadowed in this direction by the labours of a few, as yet hardly recognised, pioneers.

Moral and Political Philosophy.-On the theoretic side Psychology lies at the base of any sound treatment of the phenomena of will and conduct, the relation of the individual to his social and political environment, the meaning and bearing upon human life of legal and State organisation. The treatment of these subjects has attracted the best minds at the highest stages of social development, both in ancient and modern times, from Plato and Aristotle to John Stuart Mill and Henry Sidgwick.

Logic and Metaphysics.-On still another side Psychology is an introduction to Logic, the science which seeks to analyse the processes followed by the reason alike in ordinary affairs and in the more familiar kinds of scientific investigation, and while offering a practical discipline in logical method and the conduct of the understanding leads in turn to METAPHYSICS or General Philosophy; which may be defined as the examin ation of the relation of the forms under which we know the

NO. I 73 I, VOL. 67] world around us-matter, motion, life, intelligence, art, science, religion-to one another, to reality in general, and (under the name Theol.ogy) to the Divine Mind.

Zoology :-The study of animal life, from the lowest anneba to the highest mammal. On the practical side Zoologists are sent out by the Colonial Office to Ceylon to renovate the Oyster and Pearl Fishery there; by County Councils to study and improve the conditions of the sea-fishing industry round our coasts. The science has an important bearing on many of the operations of farmers, beekeepers, pigeon fanciers and veterinary surgeons; and in the United States a knowledge of many roological facts, relating to sheep and cattle, as well as to blight, the Colorado beetle, potato-bug, and such like pests, is disseminated among farmers by a series of pamphlets issued by the United States Department of Agriculture. Zoologists are beginning to take their part also with the botanists and pathologists in the extermination of malarial and tropical disease, in which a knowledge of the life-history of the mosquito and such like insects is so important ; and already it is coming to be more than suspected, especially in the light of South African enteric experience, that flies and o:her household insects are specifically dangerous, too.

A knowledge of Elementary Zoology, or at least of Com. parative Anatomy and Physiology, is insisted on in every medical school.

The science of Zoology is sometimes sneered at as having to do with grubs, and buttertlies, and snails; and so it has; but, though it has made no adequate beginning as yet, the greatest of problems lies before it - or before it and Physiology together - in the future, viz. the elaboration of a theory of the nature of life and death.

\section{Concluning Explanation}

In venturing to name earlier in this pamphlet (see p. 193) such a sum as five millions, I have had in view certain consider. ations which it may be well to set forth.

First it has been found that the Carnegie donation to Scottish Universities is insufficient to attain its objects, and already it appears likely that it may have to be doubled.

Next it is well known, and indeed painfully familiar to all who have to do with administration, that every new department started, and every new building erected, means an increase of current expenditure and a drain upon resources. Expenditure is called for on behalf of rates, portering and cleaning, heating and lighting, maintenance, depreciation and supersession of equipment, and materials for experiments and processes. There are also annual grants to be made to the Library, to the various Laboratories and Museums, and to departmental Libraries. Then there is a large disbursement for salaries of demonstrators and curators and assistants and technical instructors. All these expenses come out of revenue, and are probably best provided for by the income derived from fees, and from the contemporary support of County and other bodies so as to preserve dependence on the interest of the living generation. But it is highly desirable to keep fees low-not by any means to abolish them, but to keep them low-so as to bring higher education within reach of all who are able to make use of it : a number which, with the im. provement of schools, will probably be rapidly increasing. Hence it is probable that the above-mentioned items of annual expenditure will absorb the whole of the ordinary annual income and leave nothing for the payment of the chief P'rofessors and Lecturers. Everywhere it has been found essential that chairs shall be endowed, so as to put them on a permanent and substantial basis; moreover, it is vitally important to be able to attract the best men, wherever they are to be found. At the present time it is not usually possible to compete with other places for the best men unless we can offer a sum comparable to $1000 l$. a year, and in some subjects more.

An invested million will therefore on the average relieve the annual income of the stipends for 30 principal chairs. There must be a large number of Lectureships, or subsidiary and supplemental chairs, and 60 of these at $500 l$. each could be provided with the second million.

The buildings already in progress on the new site are to cost more than a quarter of a million, and the remainder of what has been sketched out and actually contemplated will cost the other three-quarters. Another half million at least will be needed to equip them properly. 
The older or central site will also need considerable enlargement, and fresh buildings should rise there. Half a million may be set aside for ultimate building and equipment on and near the Mason College site.

Four out of the five millions are thus accounted for ; the fifth is intended for a real attempt at scientific research in all departments. A fund by which men could be sent to any part of the world: to study tropical diseases, or fisheries, or mining possibilities-to investigate either nascent industries or injured industries of any kind; a fund which could equip research laboratories at home, and could defray the expense of researches undertaken on a large or engineering scale, so as to bring in rapidly some practical results. At present there are men who perceive how many things could be reformed or improved, whether in purification of the atmosphere, or in novel modes of locomotion, or in many other ways; but they lack the means to demonstrate their plans or to try experiments. Manufacturers and Municipalities sometimes try experiment on a very extensive scale indeed-a really commercial scale-and in case of failure the resulting experience is over-dear. The endowment would not allow experiments on such a scale as that ; considering the variety of subject, the amount available for each would permit of no extravagance. Some of the experiments undertaken would undoubtedly fail, yet the success of a few would far more than compensate for the failure of many, and the activity could not but conduce to progress.

The fund would have to provide, not only the necessary appliances and assistance, but it would endow fellowships for post graduate study, and would attract workers from many parts of the world, and certainly from the Colonies.

One Principal could not possibly supervise all the multifarious activities which we have thus supposed may some day be called into being. There would have to be a Research Principal (whatever he might be called), to organise and superintend the scientific and post graduate study; a Technical Director, in touch with all the technical departments; and an Educational or General Head, to supervise the general scheme of the College in all its various avenues to a degree, and to take a lead in whatever conduced to general culture.

If the scheme is lavish it represents lavishness in the right place. It is the kind of lavishness for which the nation is waiting-one of the few kinds of which hitherto it has been afraid.

\section{"There is that scattereth but yet increaseth: \\ There is that withholdeth more than is meet, but it tendeth to poverty."}

These lines refer not to individual wealth alone, but to National wealth also. We have failed to make the most hitherto of the brains and energy of our more able and specially-gifted youth, but have cramped them by the necessity of earning a living: a process wholesome enough for the individual, and right for 999 out of every thousand, but for the remaining one far less repaying to the Commonwealth than the special service which he could render, if set free and encouraged by suitable surroundings for a few years of research, following on a thorough educational preparation. Not all of these would justify their selection : nine-tenths of them even might do only moderately well ; but the discoveries of the select tenth would be of incalculable value. The world has been wasteful of its genius hitherto. It thinks too facilely that people exceptionally endowed will struggle to the front somehow. A few do, but a number do not; the conditions are not favourable; and the struggle for existence, though doubtless a stimulating training for the hardier and sturdy virtues, is not the right atmosphere for the delicate plant called genius. Different kinds of treatment are suited to different characters, and the hothouse plant will not thrive in bracing arctic air.

From the Trust Deed with which Mr. Carnegie has endowed a research Institution at Washington with ten million dollars, I extract the following altogether admirable statement of "aims":-

"1.-To promote original research; paying great attention thereto, as one of the most important of all departments.

"2. - To discover the exceptional man in every department of study, whenever and wherever found, inside or outside of schools; and to enable him to make the work for which he seems specially designed his life work.

"6.-To ensure the prompt publication and distribution of the results of scientific investigation; a field considered highly important.

$$
\text { No. } 1731 \text {, voL. 67] }
$$

"The chief purpose of the founder being to secure if possible for the United States of America leadership in the domain of discovery, and the utilisation of new forces for the benefit of man."

\section{MUTUAL AID.}

Mutual Aid, a Factor of Evolution. By P. Kropotkin. Pp. xix + 348. (London: Heinemann, 1902.)

THIS book is undeniably readable throughout. The author has a creed which he preaches with all the fervour of genuine conviction. $\mathrm{He}$ is anxious to make converts, but his zeal never leads him to forget fairness and courtesy. Those who disagree with him may learn much by studying the book.

The line of argument is, briefly, as follows. In the case of animals, there is very little evidence of any struggle for existence among members of the same species, though plants, beyond all doubt, jostle their own kin out of existence. Animals are, as a rule, banded together for mutual protection, and those that have the best organisation for mutual defence are those that thrive best. Such species are represented by large, often by countless, flocks. Those that are least sociable, such as the great carnivores, are far less vigorous, to judge by their small numbers, and barely hold their own. The term "struggle for existence" should not, therefore, be used in a literal sense, as if there were an unceasing in . ternecine war between the members of the same species, a limited amount of food available and no individual able to dispel the cravings of hunger except by robbing his own kin and reducing them to starvation. So far from this, we see mutual aid almost everywhere. There is a struggle for existence, but only in a wide, a metaphorical, sense. There is at normal times plenty of food, and there is, therefore, no need for fighting among the members of a species. Rats are a painful exception, and the cries of distress that come from cellars tell of their fights and their cruelty.

Turning to men, we find that mutual aid is, or at any rate has been in the past, even more general than among animals. Among savages, mutual aid is the chief factor in evolution. The individual is never isolated, but is one of a clan. Among barbarians, we find the same tendency to sociability and cooperation, but historians, by dwelling exclusively on wars, have misrepresented the facts. When the clan broke up, men formed village communities. So unwilling were they to fight that they got soldiers to protect them, and in many cases became the slaves of their protectors. The risk of this led to the growth of the mediæual town; it was a union of several village communities for defence against marauders. Within the larger community of the town were smaller associations, the guilds. In these mediæval towns, the arts flourished to an extraordinary degree. Sometimes leagues of free cities were formed, and held their own against all enemies. But in time these little homes of freedom disappeared. The big centralised State arose and crushed out those smaller communities that existed for mutual help. Within the State has sprung up an individualistic civilisation, but even now there is an enormous amount of mutual help. There are benefit societies, cooperative associations, trades' unions. 